\title{
An observational study to assess feto-maternal outcome in severely ill COVID-19 positive pregnant females admitted at dedicated COVID care center of southern Rajasthan
}

\author{
Pooja Meena*, Savitri Verma, Aayush Jourwal, Sudha Gandhi, Sangeeta Tvinwal
}

Department of Obstetrics and Gynaecology, RNT Medical College, Udaipur, Rajasthan, India

Received: 23 July 2021

Accepted: 13 August 2021

\author{
*Correspondence: \\ Dr. Pooja Meena, \\ E-mail: Sbapna.1@gmail.com
}

Copyright: (C) the author(s), publisher and licensee Medip Academy. This is an open-access article distributed under the terms of the Creative Commons Attribution Non-Commercial License, which permits unrestricted non-commercial use, distribution, and reproduction in any medium, provided the original work is properly cited.

\begin{abstract}
Background: COVID-19 infection is caused by corona virus SARS-COV2. the aim of the study is to assess fetomaternal outcome in severely ill covid positive pregnant females.

Methods: An observational study was conducted at dedicated covid care center, RNT medical college Udaipur from Jan 2021 to May 2021 among pregnant females. In this study out of 236 total covid positive pregnant patients, 54 patients which could not maintain oxygen saturation, according to NIH criteria were included in our study.

Results: Out of 54 pregnant women, 24 women delivered with 2 twin pregnancies. Out of this $67 \%$ underwent cesarean section and $33 \%$ were delivered by vaginal route. Postpartum hemorrhage seen in $29 \%$ of patients. Maternal death reported in $39 \%$ of patients. Out of 54 patients 38 patients were admitted in ICU. Invasive ventilation received by $26 \%$ of patients while oxygen received by non-invasive ventilation (15\%), Bains (18\%) rest by NRBM and venturi mask $(41 \%)$. Remdesivir were given in $26(48 \%)$ patients.

Conclusions: Our study suggests there may be increased risk of adverse pregnancy outcome for mother and fetus. COVID-19 in pregnancy was associated with risks of pre-eclampsia, stillbirth, preterm birth, PPH. Similar to general population comorbidities do play a role in the outcome of disease in pregnancy. Further studies are needed for effective strategies to prevent adverse outcomes in pregnant females with COVID-19.
\end{abstract}

Keywords: COVID-19, PPH, NICU

\section{INTRODUCTION}

COVID-19 infection is caused by corona virus SARSCOV-2. It was declared a pandemic on 11 march 2020 by WHO. It is a multisystem disease ranging in severity from asymptomatic to fatal. physiological Adaptations in normal pregnancies, mainly cardiorespiratory and immune are known to increase the susceptibility of pregnant women to several infectious agents. ${ }^{1}$ Physiological adaptations of pregnancy such as diaphragmatic elevation, edema of respiratory tract mucosa and increased oxygen consumption makes pregnant women are more prone to develop severe pneumonia and hypoxemic respiratory failure due to COVID-19 pneumonia. $^{2,3}$ pregnancy is a hypercoagulable state due to increased procoagulant factors which further contribute to increased COVID-19 morbidity. ${ }^{4}$ There appears to be high chances of adverse feto-maternal outcome including need for admission to ICU, endotracheal intubation, ARDS, MODS (multiple organ dysfunction syndrome) and even death, Also high incidence of still birth, fetal growth restriction and preterm birth is expected during pregnancy., 5,7 There is immunomodulatory effect there is a shift in the balance between Th1 (T helper 1) associated and Th 2 (T helper 2) associated cytokines. The cell mediated immune response is downregulated causing a $\mathrm{Th} 2$ dominant. humoral 
immune response which allows for immune tolerance to developing fetus but also contributes to increased susceptibility to viral infection in particular respiratory pathogens. ${ }^{8,9}$ Th1 immune mediated response plays a imp role in COVID-19. Elevation of Th-1 associated cytokines e. g., IL-6 has been associated with poor outcome in COVID-19 patients. SARS-COV 2 is transmitted by respiratory droplets, direct contact with fomites, close person to person contacts and possibly by aerosols generated which enters the body via the nasal passage and infect pulmonary cells via SARS-COV2 receptors angiotensin enzyme 2 (ACE2) and uses transmembrane serine protese 2 . It causes pyroptosis, inflammation mediated programmed cell death. ${ }^{10}$

\section{Aims and objectives}

Aim of our study to describe demographics, clinical characteristics, laboratory findings and feto-maternal outcome in severely ill covid positive pregnant females. For better characterization of COVID-19 infection in clinically ill pregnant patients to guide decision making regarding early intervention and feto-maternal surveillance.

\section{METHODS}

An observational study was conducted at dedicated covid care center, RNT medical college, Udaipur from Jan 2021 to May 2021 among pregnant females. Total 236 pregnant females were admitted in this duration. According to National institutes of health covid 19 disease criteria of severe disease are as follows oxygen saturation less than $94 \%$ on room air, oxygen requirement, respiratory rate greater than 30 breaths per minute, ratio of PAO2: $\mathrm{FiO}_{2}$ less than 300 , chest imaging with greater than $50 \%$ lung involvement. In this study all severely ill covid positive females which could not maintain oxygen saturation, met the criteria for inclusion in our study. Out of 236 total covid positive pregnant patients, 54 patients were included as per criteria and followed till discharge/death. Asymptomatic positive females were excluded. A complete history of patients including present complaints, past obstetric, medical, surgical, family history was taken. Patient's clinical examination done with all precautions. RT- PCR testing was done based on clinical symptoms of covid (cough, fever, myalgia, chest pain, dyspnea). All data regarding patient's status, mode of delivery, baby details were collected. Feto-maternal prognosis explained to relatives and patient.

\section{RESULTS}

The $2 \%$ were of age group $<20$ year, $48 \%$ women were of 21-25 year of age, $30 \%$ women were of 26-30 year of age group, $20 \%$ women were of $>30$ years of age group (Figure $1)$.

In our study $44 \%$ patients were primi, $56 \%$ of patients multiparous (Figure 2).

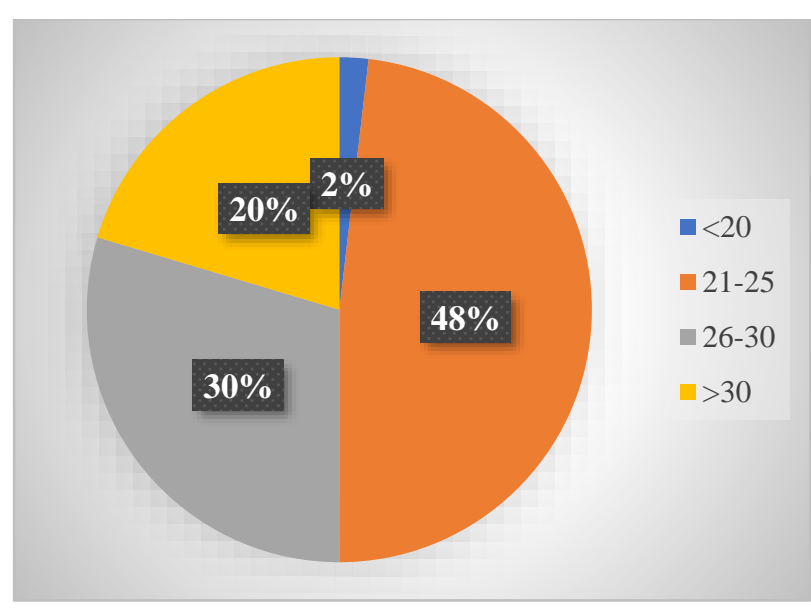

Figure 1: Age distribution of patients.

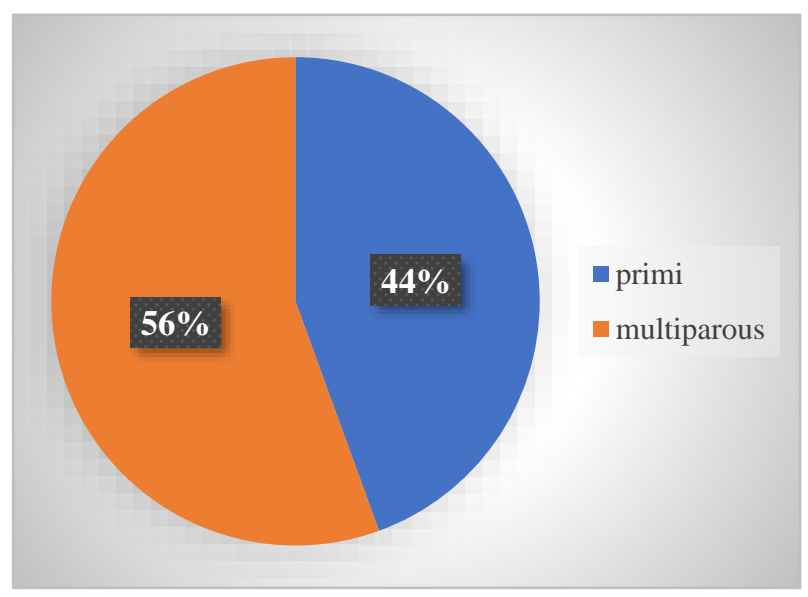

Figure 2: Distribution of patients according to parity.

Table 1: Gestational age on admission.

\begin{tabular}{|lll|}
$\begin{array}{l}\text { Gestational age } \\
\text { (Weeks) }\end{array}$ & $\begin{array}{l}\text { No. of } \\
\text { patients }\end{array}$ & $\begin{array}{l}\text { Percentage } \\
(\%)\end{array}$ \\
\hline$>$ 37 & 13 & 24 \\
\hline $\mathbf{3 4 . 1 - 3 6 . 6}$ & 12 & 22 \\
\hline$<34$ & 29 & 53 \\
\hline
\end{tabular}

Most of patients were of $<34$ week of gestational age group.

Table 2: Associated comorbidities.

\begin{tabular}{|lll|}
\hline Comorbidity & $\begin{array}{l}\text { No. of } \\
\text { patients }\end{array}$ & $\begin{array}{l}\text { Percentage } \\
(\%)\end{array}$ \\
\hline Diabetes & 1 & 1.85 \\
\hline Preeclampsia/ eclampsia & 12 & 22.22 \\
\hline Hypothyroidism & 4 & 7.40 \\
\hline Anemia & 17 & 31.48 \\
\hline
\end{tabular}

In $2 \%$ of patient's diabetes present. Eclampsia and preeclampsia were seen in $4 \%$ and $18 \%$ of patients respectively. Anemia and hypothyroidism were seen in $31 \%$ and $7 \%$ of patients. None of patients had past history of Asthma or cardiovascular disease. 
Table 3: Symptoms observed in patients.

\begin{tabular}{|c|c|c|}
\hline Symptoms & $\begin{array}{l}\text { No. of } \\
\text { patients }\end{array}$ & $\begin{array}{l}\text { Percentage } \\
(\%)\end{array}$ \\
\hline Fever & 40 & 74.07 \\
\hline Cough & 38 & 70.37 \\
\hline Dyspnea & 46 & 85.18 \\
\hline Sore throat & 12 & 22.22 \\
\hline Diarrhea & 2 & 3.70 \\
\hline Myalgia & 24 & 44.44 \\
\hline
\end{tabular}

Most prevalent symptom was dyspnea, it was seen in $85 \%$ of patients, followed by fever $\mathrm{n}$ cough were seen in $74 \%$ and $70 \%$ of patients respectively.

Table 4: Laboratory finding observed in patients, on day of admission.

\begin{tabular}{|lll|}
\hline Findings & $\begin{array}{l}\text { No. of } \\
\text { patients }\end{array}$ & $\begin{array}{l}\text { Percentage } \\
(\%)\end{array}$ \\
\hline $\begin{array}{l}\text { Radiographic imaging } \\
\text { on chest imaging }\end{array}$ & 38 & 70.37 \\
\hline Elevated CRP & 26 & 48.14 \\
\hline Elevated IL -6 & 15 & 27.77 \\
\hline Thrombocytopenia & 17 & 31.48 \\
\hline Lymphopenia & 21 & 38.88 \\
\hline Leukocytosis & 20 & 37.03 \\
\hline Abnormal LFT & 10 & 18.51 \\
\hline Abnormal RFT & 9 & 16.66 \\
\hline Elevated d- dimer & 20 & 37.03 \\
\hline
\end{tabular}

In our study lymphopenia, leukcytosis, elevated CRP were seen in 39\%,37\% and $48 \%$ respectively. Elevated IL6 and elevated dimer were seen in $28 \%$ and $37 \%$ of patients respectively.

Table 5: Supportive therapy.

\begin{tabular}{|c|c|c|c|}
\hline \multicolumn{2}{|l|}{ Outcome } & $\begin{array}{l}\text { No. of } \\
\text { patients }\end{array}$ & $\begin{array}{l}\text { Percentage } \\
(\%)\end{array}$ \\
\hline \multicolumn{2}{|c|}{ Admission to ICU } & 38 & 62.96 \\
\hline \multicolumn{2}{|c|}{ invasive ventilation } & 14 & 25.92 \\
\hline \multirow[t]{3}{*}{ Oxygen } & NIV & 8 & 15 \\
\hline & Bains & 10 & 18.5 \\
\hline & $\begin{array}{l}\text { NRBM } \\
\text { and } \\
\text { venturi } \\
\text { mask }\end{array}$ & 22 & 40.7 \\
\hline \multicolumn{2}{|c|}{ Remdesivir } & 26 & 48 \\
\hline \multicolumn{2}{|c|}{$\begin{array}{l}\text { Blood and blood } \\
\text { products }\end{array}$} & 9 & 16.66 \\
\hline
\end{tabular}

Out of 54 patients 38 patients were admitted in ICU. All patients were on oxygen support and broad-spectrum antibiotics. Invasive ventilation received by $26 \%$ of patients while oxygen received by noninasive ventilation $(15 \%)$, Bains $(18 \%)$ rest by NRBM and venturi mask $(41 \%)$. Blood products transfused in 9 patients. Remdesivir were given in 26 (48\%) patients.
Table 6: Pregnancy related outcome.

\begin{tabular}{|c|c|c|c|}
\hline Outcome & & $\begin{array}{l}\text { No. of } \\
\text { patients }\end{array}$ & $\begin{array}{l}\text { Percentage } \\
(\%)\end{array}$ \\
\hline \multirow{2}{*}{$\begin{array}{l}\text { Mode of } \\
\text { delivery }\end{array}$} & $\begin{array}{l}\text { Cesarean } \\
\text { section }\end{array}$ & 16 & 66.66 \\
\hline & $\begin{array}{l}\text { Vaginal } \\
\text { delivery }\end{array}$ & 8 & 33.33 \\
\hline \multirow{4}{*}{$\begin{array}{l}\text { Maternal } \\
\text { complications }\end{array}$} & $\mathrm{PPH}$ & 7 & 29.16 \\
\hline & Oliguria & 7 & 13 \\
\hline & Septicemia & 5 & 9.25 \\
\hline & Dialysis & 3 & 5.55 \\
\hline \multirow{3}{*}{$\begin{array}{l}\text { Neonatal } \\
\text { outcome }\end{array}$} & $\begin{array}{l}\text { Low birth } \\
\text { weight } \\
\text { baby } \\
(<2.5 \mathrm{~kg})\end{array}$ & 13 & 54.16 \\
\hline & $\begin{array}{l}\text { Admission } \\
\text { to NICU }\end{array}$ & 7 & 29.16 \\
\hline & stillbirth & 6 & 25 \\
\hline
\end{tabular}

A total of 54 pregnant women, 24 women delivered with 2 twin pregnancies. Out of this $67 \%$ underwent cesarean section and $33 \%$ were delivered by vaginal route. Postpartum hemorrhage seen in $29 \%$ of patients. $54 \%$ of baby were $<2.5 \mathrm{~kg}, 29 \%$ babies were admitted in NICU. Maternal death reported in $39 \%$ of patients. Septicemia was seen in $9 \%$ of patients.

\section{DISCUSSION}

In our study increased incidence of death in pregnant females seen in second wave in comparison to first wave of covid 19. RNT medical college is the tertiary care center of southern Rajasthan, covered 5 districts which most of the tribal belt and tribal district of nearby state also. The main reason of high mortality due to covid is lack of awareness, delay in seeking medical treatment and admission in institution in severe condition. We followed patients until hospital discharge or death but study lacks long term follow-up data including neonatal outcomes.

A study done by Yee et al their study the proportions of leukocytosis, lymphopenia and elevated CRP levels were $36 \%, 43 \%$ and $48 \%$ respectively. ${ }^{11}$ In our study lymphocytosis, lymphopenia, elevated CRP were seen in $37 \%, 39 \%$ and $48 \%$ respectively.

In our study most prevalent symptom was dyspnea, it was seen in $85 \%$ of patients, followed by fever $n$ cough were seen in $74 \%$ and $70 \%$ of patients respectively, in study by Gao et al fever followed by dry cough being the most common clinical presentation. ${ }^{12}$

In our study $2 \%$ of patient's diabetes present. Eclampsia and preeclampsia were seen in $4 \%$ and $18 \%$ of patients respectively. A Study by Yan et al there is $7.8 \%$ with gestational diabetes, $4.3 \%$ with hypertensive disorders.

In study by Tarun et al $40 \%$ of early preterm deliveries (<34 week) and $60 \%$ were late preterm deliveries (34.1- 
36.6 week). ${ }^{13}$ In study most of patients were of $<34$ week of gestational age group in our study $53 \%$ of patients were admitted with $<34$ week and $22 \%$ were of 34.1-36.6 week

In study by Yan et al $5.2 \%$ received ventilation, $1.7 \%$ received invasive ventilation. ${ }^{14}$ In our study invasive ventilation received by $26 \%$ of patients while $70 \%$ received oxygen by non-invasive ventilation (11\%), Bains $(18 \%)$ rest by NRBM and venturi mask.

Some studies have shown that SARS-COV-2 infection may create a proinflammatory state that is followed by systemic endothelial dysfunction and preeclampsia. ${ }^{15,16}$ our finding is consistent with a 2020 study in Sweden that reported pregnant people with COVID-19 had a higher prevalence of preeclampsia. ${ }^{17}$

\section{CONCLUSION}

Although pregnant women do not seem to present an increased susceptibility to COVID-19 infection or more severe complications than non-pregnant females. Our study suggest they may be at increased risk of adverse pregnancy outcome for mother and fetus. Similar to general population comorbidities do play a role in the outcome of disease in pregnancy. At the end of study few things remain unclear whether to deliver early in the hope of improving the chest wall compliance and lung function or to treat and stabilize the patient first before subjecting her to stress of labour which may flare up the cytokine response. Secondly whether to go for an early intubation and ventilation to prevent maternal and fetal hypoxia or delay the intubation as long as possible with the aid of high flow oxygen. Both pregnancy and COVID-19 infection raise the risk of thromboembolic diseases, highlighting the need for long term follow up data in pregnant and postpartum women with COVID-19. Our study lacks the long term follow up data of pregnant women including neonatal outcome.

Funding: No funding sources Conflict of interest: None declared

Ethical approval: The study was approved by the Institutional Ethics Committee

\section{REFERENCES}

1. Somervilee LK, Basile K, Dwyer DE, Kok J. The impact of influenza virus infection in pregnancy. Fut Microbiol. 2018;13:263-74.

2. Rigby FB, Pastorek JG. 2 Pneumonia during pregnancy. Clin Obstet Gynecol. 1996;39:10719.

3. Khan S, Niederman MS. Pneumonia in the pregnant patient in: Rosene-montela K, Bourjeily G, editores. pulmonary problems in pregnancy. New York Humana press. 2009;177-96.

4. Dashraath P, Wong JLJ, Lim Mxk. corona virus disease 2019 pandemic and pregnancy. Amj obstet Gynecol. 2020;222(6):521-31.

5. Wong SF, Chow KM, Leung TN. Pregnancy and perinatal outcome of women with severe acute respiratory syndrome. Am J Obstet Gynecol. 2004;191(1):292-7.

6. Ksiazek TG, Erdman D, Gold smith CS. A novel coronavirus associated with severe acute respiratory syndrome. N Enge J Med. 2003;348(20):1953-66.

7. World Health Organization. Middle East Respiratory syndrome coronavirus (MERS-COV);nl-2019(EB/OL). 2019.

8. Reinhard G, Noll A, Schlebush H, Mallmann P, Ruecker AV. Shift in the Th1/Th2 balance during Human pregnancy correlate with apoptic changes. Biochem Res Commun. 1998;245(3):933-8.

9. Qiao J. What are the risks of COVID-19 infection in pregnant women? Lancet. 2020;395(10226):760-2.

10. Cascella M, Rajnik M, Aleem A, Dulebohn SC, Di Napoli R. Features, Evaluation, and Treatment of Coronavirus (COVID-19). 2021 Jul 17. In: StatPearls. Treasure Island (FL): StatPearls Publishing. 2021;32150360.

11. Yee J, Kim W, Han JM, Yoon HY, Lee N, Lee KE et al. Clinical manifestations and perinatal outcomes of pregnant women with COVID-19: a systematic review and meta-analysis. Scientific rep. 2020;10(1):1-7.

12. Gao YJ, Ye L, Zhang JS, Yin Yx, Liv M, Yu HB. Clinical features and outcomes of pregnant women with covid 19: a systemic review and meta-analysis. BMC infect Dis. 2020;20:564.

13. Tarun O, Hakim A, Dashraath P, Jeslyn WJL, Wright A, Abdul Kadir R. clinical characteristics, prognostic factors and maternal and neonatal outcomes of SARSCOV 2 infection Among hospitalized pregnant women: A systemic review Int J Gynecol Obstet. 2020;151(1).

14. Yan J, Gyo J, Fan C, Zhang Y, Poon L, Yang H. Corona virus disease 2019 in pregnant women; a report based on 116 cases. 2019.

15. Coronado-Arroyo JC, Conception-Zavaleta MJ, Zavaleta -Gutierrez FE. Is COVID-19 a risk factor for severe pre-eclmapsia? Hospital experience in a developing country. Eur J Obstet Gynecol Repord Biol. 2021;256:502-32.

16. Todros T, Masturzo B, Francia SD. COVID-19 infection: ACE2, pregnancy and preeclampsia. Eur $\mathrm{J}$ Obstet Gynecol Record Biol. 2020;253:330.

17. Been JV, Ochoa LB, Bertens LCM. Impact of COVID 19 mitigation measures on the incidence of preterm birth: a national quasi- experimental study. Lancet Public Health. 2020;5:e604-11.

Cite this article as: Meena P, Verma S, Jourwal A, Gandhi S, Tvinwal S. An observational study to assess feto-maternal outcome in severely ill COVID19 positive pregnant females admitted at dedicated COVID care center of southern Rajasthan. Int J Reprod Contracept Obstet Gynecol 2021;10:3375-8. 